\title{
Influencia de 6 tipos de curados en hormigones con cenizas volantes
}

\section{Influence of six types of curing on fly-ash concretes}

MARINA ALVAREZ, Dra. Arquitecta y JULIÁN SALAS, Dr. Ingeniero Industriai

\section{RESUMEN}

El trabajo presenta los resultados de series de probetas de hormigones, con tres dosificaciones distintas: a base de cemento I/45A, Portland con adiciones y ceniza volante; sometidas a seis tipos de curados diferentes, en los que se trata de estudiar la evolución de sus resistencias a compresión, en función del grado de "maduración" alcanzado a edades tempranas.

El trabajo aporta algunas recomendaciones de tipo práctico sobre la interreláción entre los procesos de curado y la resistencia a compresión. Se enmarca este trabajo en el contexto del programa de investigación sobre "Tecnologias para viviendas de interés social".

\section{SUMMARY}

This study presents the results of a series of concrete test pieces of three different mixtures: I/45A cement; Portland cement with additions; Portland with fly ash. All were subjected to six different types of curing, with the aim of studying the evolution of their compressive strengths in terms of the grade of "maturity" reached at early ages.

The study makes some practical recomendations on the interrelationship between curing processes and compressive strength and is included in the context of the research program on "Tecnologies for Housing of Social Interest".
PALABRAS ClaVe:

HORMIGONES POBRES; CURADO; MADURACIÓN RESISTENCIAS A COMPRESIÓN; CENIZA VOLANTE.

\section{MATERIALES EMPLEADOS}

Los materiales empleados fueron:

- grava procedente del río Jarama, de tamaño máximo $20 \mathrm{~mm}$ y módulo de finura 7,55;

- arena de Segovia de módulo de finura 3,13.

Y como conglomerantes:

- cemento Portland de alta resistencia inicial I/45A, de superficie específica $4.392 \mathrm{~cm}^{2} / \mathrm{g}^{\mathrm{B}}$;

- cemento de adición II-z/35 de superficie $3.560 \mathrm{~cm}^{2} / \mathrm{g}^{\mathrm{B}}, \mathrm{y}$

- una ceniza volante sílico-aluminosa (clase F) procedente de la central térmica de Soto de Ribera en Asturias.

\section{KEY WORDS:}

POOR CONCRETES: CURING: NATURITY: COMPRESSIVE STRENGTH: FLY ASH.

\section{MATERIAL EMPLOYED}

The materials employed were the following:

- gravel from the Jarama River, with a maximun size of $20 \mathrm{~mm}$ and a finennes modulus of 7.55 .

- sand from Segovia, with a finennes modulus of 3.13 .

And as binding materials:

- I/45A Portland cement of high initial strength, specific surface of $4.392 \mathrm{~cm}^{2} / \mathrm{gB}$;

- II-z/35 cement with aggregates, specific surface $3.560 \mathrm{~cm}^{2} / \mathrm{g} B$;

- a silico-aluminous fly ash (class F) from the thermal power station of Soto de Ribera in Asturias. 
Las características físicas y químicas de los cementos y de la ceniza volante, se recogen en la Tabla 1.
The physical and chemical characteristics of the cements and the fly ash are shown in Table 1.

TABLA 1 (TABLE 1)

Características físicas y químicas de los conglomerantes

(Physical and chemical characteristics of the binding materials)

\begin{tabular}{|c|c|c|c|}
\hline \multicolumn{4}{|c|}{ COMPOSICIÓN QUÍMICA (CHEMICAL COMPOSITION) } \\
\hline ELEMENTOS (ELEMENTS) & $\begin{array}{l}\text { CEMENTO } 1 / 45 A \\
\text { (CEMENT I/45A) }\end{array}$ & $\begin{array}{l}\text { CEMENTO } \mid 1-z / 35 \\
\text { (CEMENT } \mid 1-z / 35 \text { ) }\end{array}$ & $\begin{array}{l}\text { CENIZA VOLANTE } \\
\text { (FLY ASH) }\end{array}$ \\
\hline $\mathrm{SiO}_{2}$ & 19,85 & 22,87 & 50,04 \\
\hline $\mathrm{Al}_{2} \mathrm{O}_{3}$ & 5,88 & 6,00 & 31,20 \\
\hline $\mathrm{Fe}_{2} \mathrm{O}_{3}$ & 3,17 & 4,00 & 7,15 \\
\hline $\mathrm{CaO}$ & 61,32 & 53,84 & 2,84 \\
\hline $\mathrm{MgO}$ & 1,51 & 3,60 & 1,76 \\
\hline $\mathrm{Na}_{2} \mathrm{O}$ & 3,20 & - & - \\
\hline $\mathrm{K}_{2} \mathrm{O}$ & 0,78 & - & - \\
\hline $\mathrm{SO}_{3}$ & 3,00 & 2,90 & 0,52 \\
\hline $\mathrm{PF}\left({ }^{\star}\right)$ & 2,45 & 2,91 & 2,52 \\
\hline $\operatorname{RI}(\star \star)$ & 1,84 & 2,73 & 0,08 \\
\hline \multicolumn{4}{|c|}{ CARACTERISTICAS FISICAS (PHISICAL CHARACTERISTICS) } \\
\hline $\begin{array}{l}\text { Peso específico } \mathrm{g} / \mathrm{cm}^{3} \\
\text { (Specific Weight } \mathrm{g} / \mathrm{cm}^{3} \text { ) }\end{array}$ & 3,06 & 3,00 & 2,26 \\
\hline $\begin{array}{l}\text { Superficie especifica } \mathrm{cm}^{2} / \mathrm{g}^{B} \\
\left.\text { (Specific Surface } \mathrm{cm}^{2} / \mathrm{g}^{B}\right)\end{array}$ & 4.392 & 3.560 & 3.754 \\
\hline $\begin{array}{l}\text { Residuo en el tamiz de } 45 \mu(\%) \\
\text { [Residue on Screan } 45 \mu(\%)]\end{array}$ & 6 & 14,58 & 26 \\
\hline
\end{tabular}

(*) $\mathrm{PF}=\mathrm{Pérdida}$ al fuego (loos on ignition).

(**) $\mathrm{RI}=$ Residuo insoluble (insoluble residue).

\section{HORMIGONES}

Se estudiaron tres tipos de hormigones, designados por I, II y III denominados así según el tipo de conglomerante empleado. Los hormigones tipo I se realizaron con cemento I/45A, los de tipo II con II-z/35 y en el tipo III el conglomerante utilizado fue el $\mathrm{Il}-\mathrm{z} / 35$ al cual se le sustituye en un $60 \%$ en peso, por ceniza volante. Los parámetros de las dosificaciones vienen expresados en la Tabla 2.

El tipo de probetas empleadas fue la cilíndrica de $7,5 \times 15 \mathrm{~cm}$, ya que a una mayor facilidad de manejo, se suma el que la granulometría de los áridos $\varnothing$ máximo $20 \mathrm{~mm}$, cumple las recomendaciones de que el diámetro de la probeta sea al menos tres veces el tamaño máximo del árido.

\section{CONCRETE}

Three types of concretes (designated I, II, and III according to the type of binding material used) were studied. Type I concretes were made with I/45A cement; type II with $\mid I-z / 35$, and in type $|1|$ the binding material used was $11-z / 35$ substituted in $60 \%$ by weight by fly ash. The parametres of the mixtures are shown in Table 2.

Cylindrical test pieces of $7.5 \times 15 \mathrm{~cm}$ were used, since, in addition to their easy handling, their graduation of $\varnothing$ aggregates

(maximum $=20$ ) meets the recommendation that the diametre of the test piece be at least three times the maximum size of the aggregate. 
TABLA 2 (TABLE 2)

Dosificaciones estudiadas (Proportioning concretes)

\begin{tabular}{|c|c|c|c|c|c|c|c|}
\hline $\begin{array}{l}\text { DOSIFICACIÓN } \\
\text { (DOSAGES) }\end{array}$ & $\begin{array}{c}\text { CEMENTO } \\
\text { I/45A } \\
\text { (CEMENT } \\
1 / 45 A \text { ) } \\
\mathrm{kg} / \mathrm{m}^{3}\end{array}$ & $\begin{array}{c}\text { CEMENTO } \\
\text { II-z/35 } \\
\text { (CEMENT } \\
\mid I-z / 35) \\
\mathrm{kg} / \mathrm{m}^{3}\end{array}$ & $\begin{array}{c}\text { CENIZA } \\
\text { VOLANTE } \\
\text { (FLY-ASH) } \\
\mathbf{k g} / \mathrm{m}^{3}\end{array}$ & $\begin{array}{c}\text { GRAVA } \\
\text { (GRAVEL) } \\
\mathbf{k g} / \mathbf{m}^{3}\end{array}$ & $\begin{array}{l}\text { ARENA } \\
\text { (SAND) } \\
\mathrm{kg} / \mathrm{m}^{3}\end{array}$ & $\begin{array}{c}\text { AGUA } \\
\text { litros } \\
\text { (WATER } \\
\text { litres) }\end{array}$ & $\begin{array}{c}a /(C+C v) \\
{[w /(C+f a)]}\end{array}$ \\
\hline Tipo I & 287 & - & - & 1.134 & 756 & 205 & 0,71 \\
\hline Tipo II & - & 287 & - & 1.134 & 756 & 205 & 0,71 \\
\hline Tipo III & - & 114,8 & 172,2 & 1.134 & 756 & 205 & 0,71 \\
\hline
\end{tabular}

La compactación fue manual, mediante barra en dos capas, sobre las que se aplicaron doce golpes en cada una, para proceder finalmente el refrentado con cemento.

\section{TIPOS DE CURADO ESTUDIADOS}

Cada dosificación se sometió a estudio, mediante seis tipos de curado que seguidamente se especifican y que, de forma esquemática, se recogen en la figura 1 , en la que aparecen las correspondientes curvas temperaturas-tiempos.
Manual compaction with a bar was carried out in two layers, strinking twelve times on each layer, proceeding afterwards to facing with cement.

\section{TYPES OF CURINGS STUDIED}

Each mixture was studied in six types of curing to be immediately specified below and which, in schematic form, are found in Figure 1, which includes the corresponding temperature-time curves.

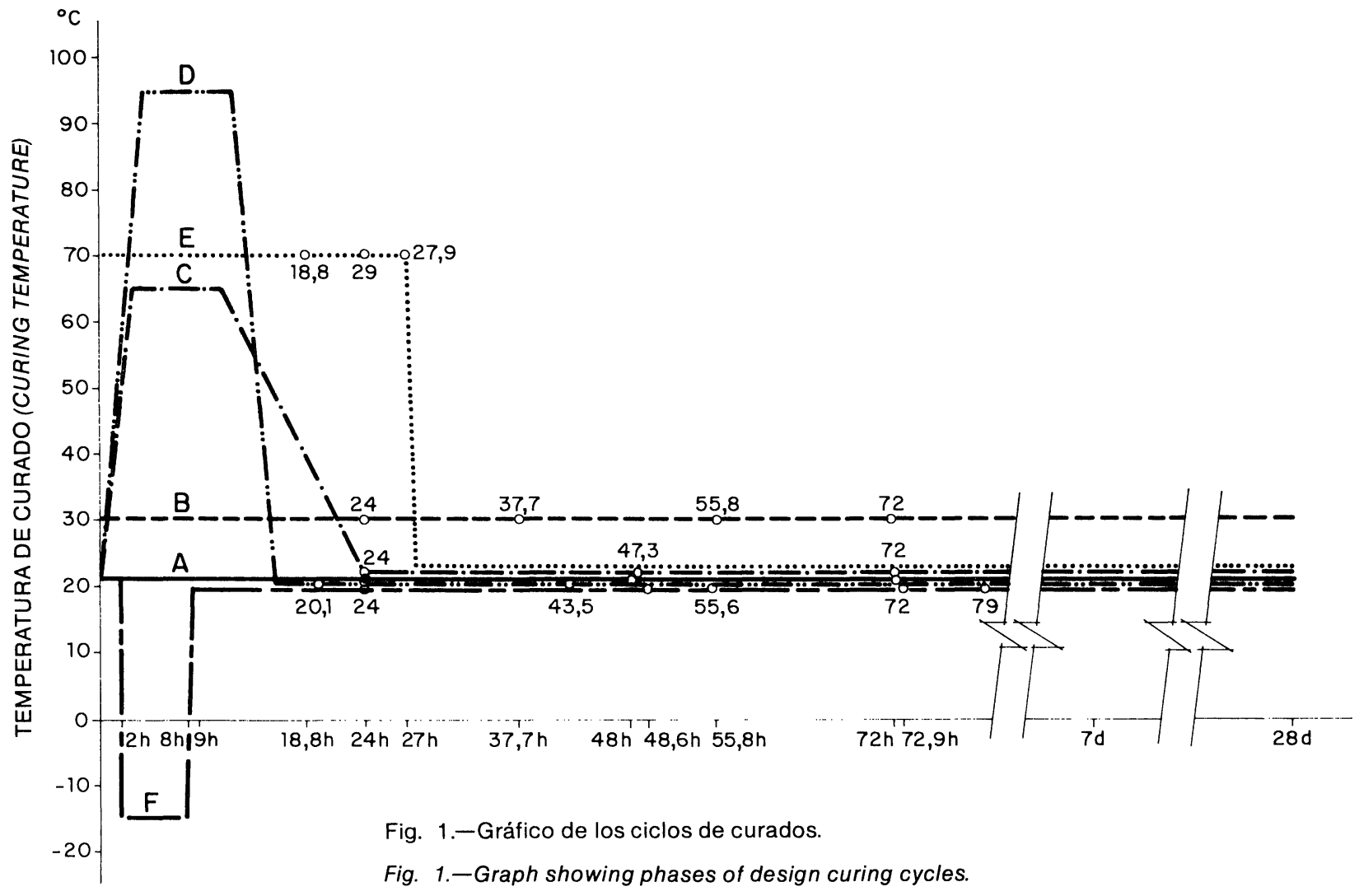




\subsection{Curado "tipo A". (Curado normalizado)}

Las probetas, una vez refrentadas, pasaban en el molde a una cámara a $21^{\circ} \mathrm{C} \pm 1^{\circ} \mathrm{C}$ y $95 \pm 5 \%$ HR. A las 24 horas se desmoldaban todas las probetas y continuaban en la misma cámara, hasta las distintas edades de rotura.

\subsection{Curado "tipo B". (Curado caribe)}

Se procedía de igual forma que en el caso anterior, sólo que en una cámara a $30^{\circ} \mathrm{C} \pm 2^{\circ} \mathrm{C}$ y $80 \pm 5 \% \mathrm{HR}$; valores ambos que tienden a reproducir las características climatológicas de amplias zonas geográficas del Caribe.

\subsection{Curado "tipo C". (Curado de prefabricación)}

Refrentadas las probetas, pasaban en el molde a una cámara programable tipo AMR-IEC WEISSTECHNIK (Foto 1) para seguir el ciclo de temperaturas y humedades

\section{1. "Type A" Curing. (Standard curing)}

The test pieces, once faced, were transferred in the form to a chamber at $21^{\circ} \mathrm{C} \pm 1^{\circ} \mathrm{C}$ and $95 \pm 5 \%$ R.H. After 24 hours the forms were stripped from all of the test pieces and they continued in the same chamber until their respective, different breaking ages.

\section{2. “Type B"' Curing. (Caribbean Curing)}

Carried out the same way as above, only in a chamber at $30^{\circ} \mathrm{C} \pm 2^{\circ} \mathrm{C}$ and $80 \pm 5 \%$ R.H. These values were intented to reproduce the climatic characteristics of large geographic areas of the Caribbean.

\section{3. "Type C"' Curing. (Prefabrication Curing)}

Once faced, the test pieces were transferred in form to a programmable AMR-IEC WEISSTECHNIK chamber (Photo 1) in order to undergo the cycle of temperatures and

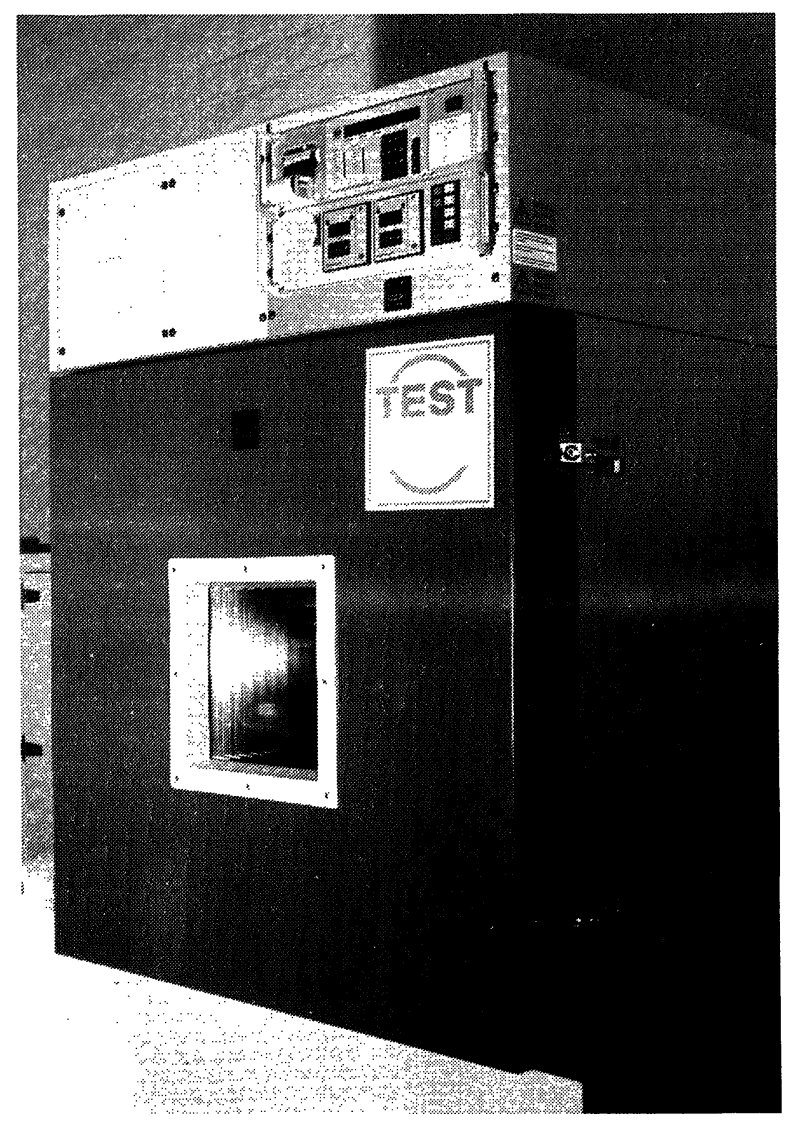

Foto 1-Cámara de temperatura-humedad-tiempo programable para el curado de las probetas.
Foto 1.-Programmable temperature-humidite-time chamber for curing test pieces. 
indicado en la figura 1 y que se detallan a continuación:

- En 3 horas pasaba de la temperatura ambiente a $65^{\circ} \mathrm{C}$ y del $45 \%$ al $90 \%$ de humedad relativa.

- Se mantenía esta temperatura y humedad durante 8 horas, tras las cuales descendía a $21^{\circ} \mathrm{C}$ y a $45 \%$ de H.R., en un período de 13 horas. Transcurrido el ciclo se desmoldaban las probetas; una serie de tres se rompía a compresión y el resto pasaba a la cámara de curado "tipo A", hasta las distintas edades de rotura.

\subsection{Curado "tipo D". (Curado experimental)}

El proceso es semejante al curado anterior "tipo C", sólo que variando el ciclo de temperaturas y humedades:

- En 4 horas se pasaba de la temperatura ambiente a $95^{\circ} \mathrm{C}$.

- Se mantenian las probetas en un molde a dicha temperatura, durante 8 horas.

- Descendía paulatinamente hasta la temperatura ambiente $\left(21^{\circ} \mathrm{C}\right)$ en 4 horas y se procedía a desmoldar las probetas, pasando éstas a la cámara de curado "tipo A" hasta el momento de su rotura.

- En cuanto a la humedad, ésta descendía paulatinamente del $95 \%$ de H.R. al $30 \%$ H.R. en 8 horas, manteniéndose a dicha humedad durante el resto del ciclo.

\subsection{Curado "tipo B". (Curado saturado)}

Las probetas en sus moldes se mantenian en un ambiente de prácticamente $100 \%$ de H.R. y a temperatura de $70^{\circ} \mathrm{C} \pm 3^{\circ} \mathrm{C}$. Transcurridas 18,8 horas (madurez $\alpha$ correspondiente a $1.507^{\circ} \mathrm{C} \cdot$ hora) se desmoldaban todas las probetas, rompiendo la primera serie; las restantes permanecian en la misma cámara hasta transcurrir 24 horas y 27,9 horas respectivamente, momento en que las probetas restantes pasaban a las condiciones de curado "tipo A", hasta su rotura.

\subsection{Curado "tipo F". (Curado con helada)}

Las probetas refrentadas, transcurridas 2 horas, pasaban en sus moldes a una cámara humidities indicated in Figure 1 and shown below.

- In 3 hours they went from room temperature to $65^{\circ} \mathrm{C}$ and from $45 \%$ to $90 \%$ relative humidity.

- This temperature and humidity were maintained for 8 hours, after which it descended to $21^{\circ} \mathrm{C}$ and $45 \%$ H.R., over a period of 13 hours. Once the cycle was completed, the test pieces were stripped, a series of three were broken by compresion and the rest were transferred to a "type A" curing chamber until their different breaking ages.

\section{4. "TYPE D" Curing. (Experimental Curing)}

The process is similar to the previous one, except that the cycle of temperatures and humidities is different:

- In 4 hours they went from room temperature to $95^{\circ} \mathrm{C}$.

- The test pieces were kept in the form at said temperature for 8 hours.

- After cooling slowly to room temperature $\left(21^{\circ} \mathrm{C}\right)$ in 4 hours, the test pieces were stripped and them transferred to a "Type A" curing chamber until the time of their breaking.

- The relative humidity descended slowly from $95 \%$ to $30 \%$ R.H. in 8 hours. Said relative humidity was maintained for the rest of the cycle.

\section{5. “Type E' Curing. (Saturated Curing)}

The test pieces and their forms were kept in an environment of practically $100 \%$ R.H. and at a temperature of $70^{\circ} \mathrm{C} \pm 3^{\circ} \mathrm{C}$. After 18.8 hours (maturity $\alpha$; corresponding to $1.507^{\circ} \mathrm{C} / \mathrm{h}$ ) the test pieces were stripped, the first series broken, and the rest kept in the same chamber for 24 hours and 27.9 hours, respectively, when the remaining test pieces were transferred to conditions of "Type A" curing until their breaking.

\section{6. "Type F" Curing. (Curing with Freezing)}

Once faced, and after 2 hours, the test pieces were transferred in their forms to a chamber 
$\mathrm{a}-15^{\circ} \mathrm{C}$, donde permanecian 6 horas. Se procedía al desmoldeo de todas las probetas, rompiendo la primera serie y pasando las restantes a la cámara de curado en idénticas condiciones al "tipo A", hasta la rotura.

\section{EL CONCEPTO DE "MADURACIÓN" DEL HORMIGÓN}

Es abundante la literatura referente a los procesos de curado del hormigón que se ocupa del fenómeno de la "maduración" ("maturity") aunque, en general, se trata el tema en forma empírica y sin el aporte de datos cuantitativos. Se suele aceptar la regla de maduración propuesta por Nurse-Saul (1) (2) que toma como temperatura de inicio de la hidratación $\left(-10^{\circ} \mathrm{C}\right)$ según los resultados experimentales.

Más recientemente pueden citarse algunos trabajos sobre el tema, realizados en Japón (3) (4).

En este trabajo se ha adoptado, como parámetro de medida de la maduración del hormigón a corta edad, el producto de los grados centígrados por el tiempo en horas trancurrido (tomando como origen de temperaturas $-10^{\circ} \mathrm{C}$ ), es decir, el valor de la integral de la curva tiempo-temperatura, representativa del proceso de curado. Kohno, Horii y Fukushima (5), por el contrario, adoptaron como base $0^{\circ} \mathrm{C}$, en el trabajo al que nos referiremos más adelante.

En base al parámetro de medida de la madurez del hormigón adoptada (M) y de acuerdo con las seis curvas de curado de la figura 1, pueden expresarse los siguientes algoritmos de cálculo:

- Curado "tipo A": $M=\left(21^{\circ}+10^{\circ}\right) \mathrm{t}$.

- Curado "tipo B": $M=\left(30^{\circ}+10^{\circ}\right) \mathrm{t}$.

- Curado "tipo C": $M=1.507^{\circ} \mathrm{C} \cdot \mathrm{h}+$ +31 ( $t-24)$; para $t \geq 24,0$ horas.

- Curado "tipo D": $\mathrm{M}=1.360^{\circ} \mathrm{C} \cdot \mathrm{h}+$ $+31(\mathrm{t}-16)$; para $\mathrm{t} \geq 16,0$ horas.

- Curado "tipo E": $M=(70+10) t$; para $\mathrm{t} \leq 27,9$ horas.

$$
M=2232^{\circ} \mathrm{C} \cdot \mathrm{h}+
$$

+31 ( $t-27,9)$; para $t \geq 27,9$ horas.

- Curado "tipo F": $M=30^{\circ} \mathrm{C} \cdot \mathrm{h}+$ +31 ( $t-8,0)$; para $t \geq 8,0$ horas.

Al objeto de investigar el comportamiento de los tres tipos de hormigones estudiados (I; II; III), sometidos a los seis procesos de curado definidos (A; B; C; D; E; F), se procedió at $-15^{\circ} \mathrm{C}$, where they remained 6 hours. The test pieces were stripped, the first series broken and the rest transferred to identical conditions to that of "Type A" until their breaking.

\section{THE CONCEPT OF CONCRETE "MATURITY",}

There is abundant literature on concrete curing processes which considers the phenomenon of "maturity"; nevertheless, it generally deals with the theme in empirical form and without giving quantiative data. The rule of maturity proposed by Nürs-Saul (1) (2) is generally accepted, and takes as temperature at the start of hydration $\left(-10^{\circ} \mathrm{C}\right)$, according to experimental results.

More recent studies on the subject have been carried out in Japan (3) (4).

In this study, the product of degrees centigrade multiplied by the time passed in hours (taking as origen of temperatures $-10^{\circ} \mathrm{C}$ ) has been adopted as the parametre of the measurement of the maturity of concrete at an early age. In other words, the value of the integral of the time-temperature curve, representative of the curing process. Kohno, Horii and Fukushima (5), on the other hand, adopted $0^{\circ} \mathrm{C}$ as the base in the study which we referred to above.

Based on the measurement parametre of concrete maturity adopted (M) and according to the six curing curves in figure 1, the following calculation algorithms can be expressed:

$$
\begin{aligned}
& \text { - “Type A" curing: } M=\left(21^{\circ}+10^{\circ}\right) t ; \\
& \text { - “Type B" curing: } M=\left(30^{\circ}+10^{\circ}\right) t ; \\
& \text { - “Type C" curing: } M=1507^{\circ} \mathrm{C.h} .+ \\
& \quad+31(t-24) ; \text { for } t \geq 24.0 \mathrm{hrs} . \\
& \text { - “Type } D \text { " curing: } M=1360^{\circ} \mathrm{C.h} .+ \\
& \quad+31(t-16) ; \text { for } t \geq 16.0 \mathrm{hrs} . \\
& \text { - “Type E" curing: } M=(70+10) t ; \\
& \text { for } t \leq 27,9 \text { hrs. } \\
& \quad M=2232^{\circ} \mathrm{C.h} .+ \\
& \quad+31(t-27.9) ; \text { for } t \geq 27.9 \mathrm{hrs} . \\
& \text { - "Type F" curing: } M=30^{\circ} \text { C.h. }+ \\
& \quad+31(t-8.0) ; \text { for } t \geq 8.0 \mathrm{hrs} .
\end{aligned}
$$

With the object of studying the behaviour of the three types of concretes in question $(I, I)$, III) subjected to six defined curing processes $(A, B, C, D, E, F)$, the compression breaking 
a la rotura a compresión de series de tres probetas por cada edad, siguiendo los siguentes criterios de plazos de roturas:

* A plazo fijo: $1 ; 3$ y 28 dias.

* Al alcanzar los siguientes grados de maduración:

$\alpha$, correspondiente a las 24 primeras horas del curado "tipo C", equivalentes a $1.507^{\circ} \mathrm{C} \cdot \mathrm{h}$

$\beta$, correspondiente a 72 horas de curado "tipo A" equivalente a $2.232^{\circ} \mathrm{C} \cdot \mathrm{h}$.

* Al desmoldar las probetas en los seis tipos de curado.

De acuerdo con estos criterios, en la Tabla 3 se recogen las fechas de rotura $y / 0$ el grado de madurez alcanzado en ese momento para los seis tipos de curado. of series of three test pieces per each age was carried out, following these time-period criteria for breaking:

* Upon a fixed period: 1, 3, and 28 days;

* Upon reaching the following grades of maturity:

$\alpha$ corresponding to the first 24 hours of "Type C" curing, equivilent to $1507^{\circ} \mathrm{C} \cdot h$.

$\beta$, corresponding to 72 hours of "Type $A$ " curing equivilent to $2232^{\circ} \mathrm{C} \cdot h$.

* Upon stripping the test pieces in the six types of curing.

Table 3 shows the dates of breaking and/or the grade of maturity reached at this moment for the six types of curing according to the above criteria.

TABLA 3 (TABLE 3)

Edades y/o grado de madurez de las series de probetas ensayadas (Ages and/or grade of maturity of the series of test pieces used)

\begin{tabular}{|c|c|c|c|c|c|c|c|}
\hline \multirow{2}{*}{$\begin{array}{l}\text { TIPO DE } \\
\text { CURADO } \\
\text { (TYPE OF } \\
\text { CURING) }\end{array}$} & \multicolumn{2}{|c|}{$\begin{array}{l}\text { DESMOLDEO } \\
\text { (STRIPPING) }\end{array}$} & \multicolumn{2}{|c|}{$\begin{array}{l}\text { GRADO DE MADUREZ } \\
\text { (GRADE OF MATURITY) }\end{array}$} & \multicolumn{3}{|c|}{$\begin{array}{l}\left.\text { PLAZO FIJO (EN }{ }^{\circ} \mathrm{C} \cdot h\right) \\
\text { (FIXED PERIOD }\left(\text { IN }^{\circ} \mathrm{C} \cdot \mathrm{h}\right)\end{array}$} \\
\hline & $\begin{array}{l}\text { Edad } \\
\text { (Age) }\end{array}$ & $\begin{array}{l}\text { Grado } \\
\text { (Grade) }\end{array}$ & $\begin{array}{c}\alpha=1.507^{\circ} \\
\text { C. } h\end{array}$ & $\begin{array}{c}\beta=2.232^{\circ} \\
\mathbf{C} \cdot \mathbf{h}\end{array}$ & $\begin{array}{l}1 \text { dia } \\
\text { (1 day) }\end{array}$ & $\begin{array}{l}3 \text { dias } \\
\text { ( } 3 \text { days) }\end{array}$ & $\begin{array}{l}28 \text { días } \\
\text { (28 days) }\end{array}$ \\
\hline "A" & $24 \mathrm{~h}$ & $744 \mathrm{C} \cdot \mathrm{h}$ & $48,6 \mathrm{~h}$ & $72,0 \mathrm{~h}$ & 744 & 2.232 & 20.832 \\
\hline "B" & $24 \mathrm{~h}$ & $960 \mathrm{C} \cdot \mathrm{h}$ & $37,7 \mathrm{~h}$ & $55,8 \mathrm{~h}$ & 960 & 2.880 & 22.344 \\
\hline "C" & $24 \mathrm{~h}$ & $1.507 \mathrm{C} \cdot \mathrm{h}$ & $24,0 \mathrm{~h}$ & $47,3 \mathrm{~h}$ & 1.507 & 2.995 & 21.595 \\
\hline "D" & $16 \mathrm{~h}$ & $1.380 \mathrm{C} \cdot \mathrm{h}$ & $20,1 \mathrm{~h}$ & $43,5 \mathrm{~h}$ & 1.628 & 3.116 & 21.716 \\
\hline “E” & $18,8 \mathrm{~h}$ & $1.507 \mathrm{C} \cdot \mathrm{h}$ & $18,8 \mathrm{~h}$ & $27,9 \mathrm{~h}$ & 1.920 & 3.599 & 22.199 \\
\hline "F" & $8,0 \mathrm{~h}$ & $30 \mathrm{C} \cdot \mathrm{h}$ & $55,6 \mathrm{~h}$ & $79,0 \mathrm{~h}$ & 526 & 2.014 & 20.614 \\
\hline
\end{tabular}

\section{RESULTADOS DE LAS ROTURAS A COMPRESIÓN}

En todos los casos, los resultados a compresión corresponden a los valores medios de series de tres probetas, obtenidos en una prensa AMSLER, empleando la escala correspondiente a $25 \mathrm{t}$.

Las edades de rotura quedan recogidas en la Tabla 3 y representadas en la Fig. 1, asi como en las Figuras 2, 3 y 4 . Con los distintos momentos de desmoldeo se corresponde la

\section{RESULTS OF THE COMPRESSION BREAKINGS}

In every case, the compression results correspond to the average values of series of three test pieces, obtained in a AMSLER press, using the scale corresponding to 25 tonnes.

Table 3 shows breaking ages, which are also represented in Figs. 1, 2, 3, and 4. They correspond to the different moments of stripping, the reaching of the two pre-set 


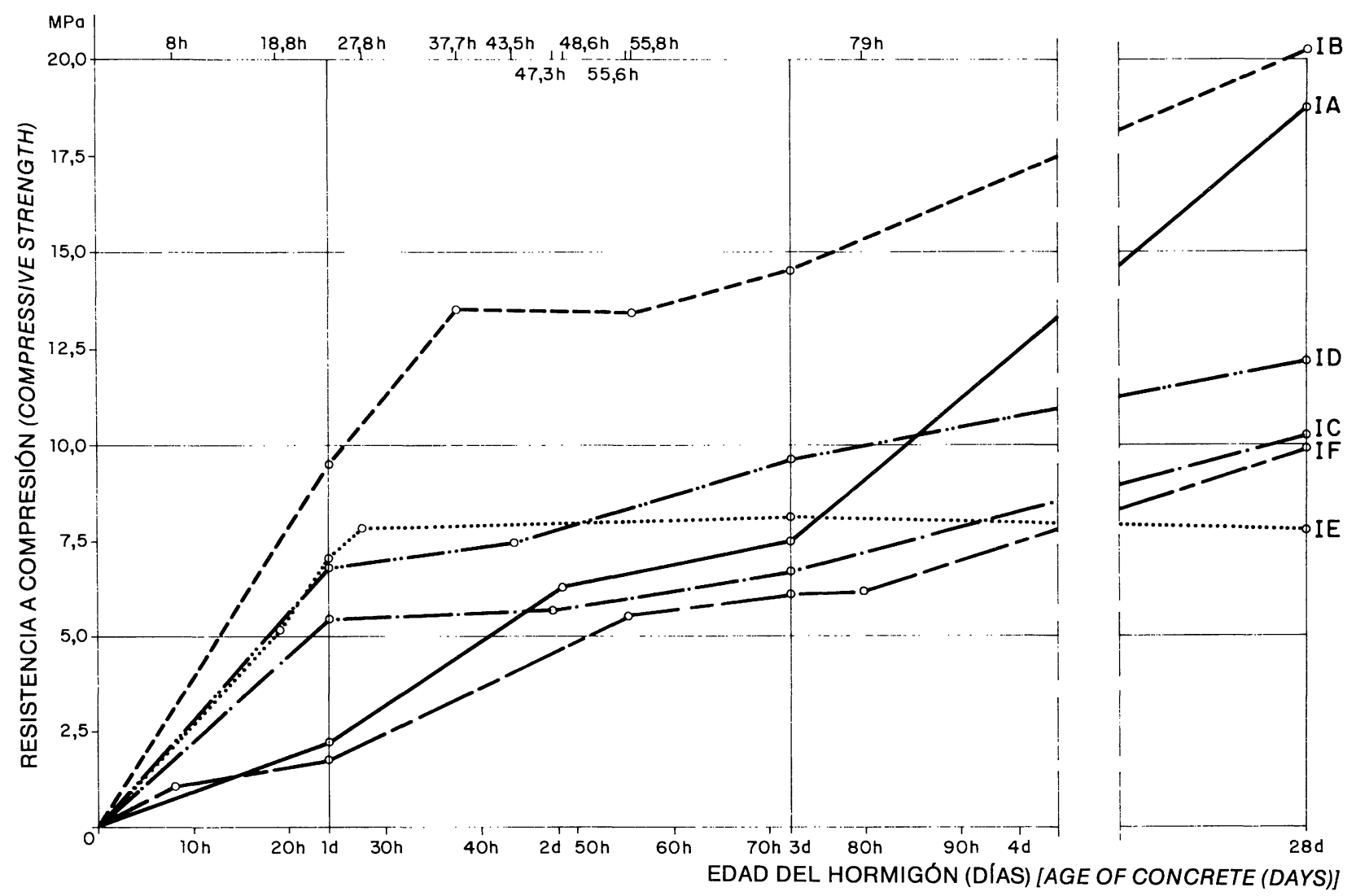

Fig. 2.-Desarrollo de resistencias del hormigón tipo I en función de los curados.

Fig. 2.-Strength development of concrete "Type I" by curing periods.

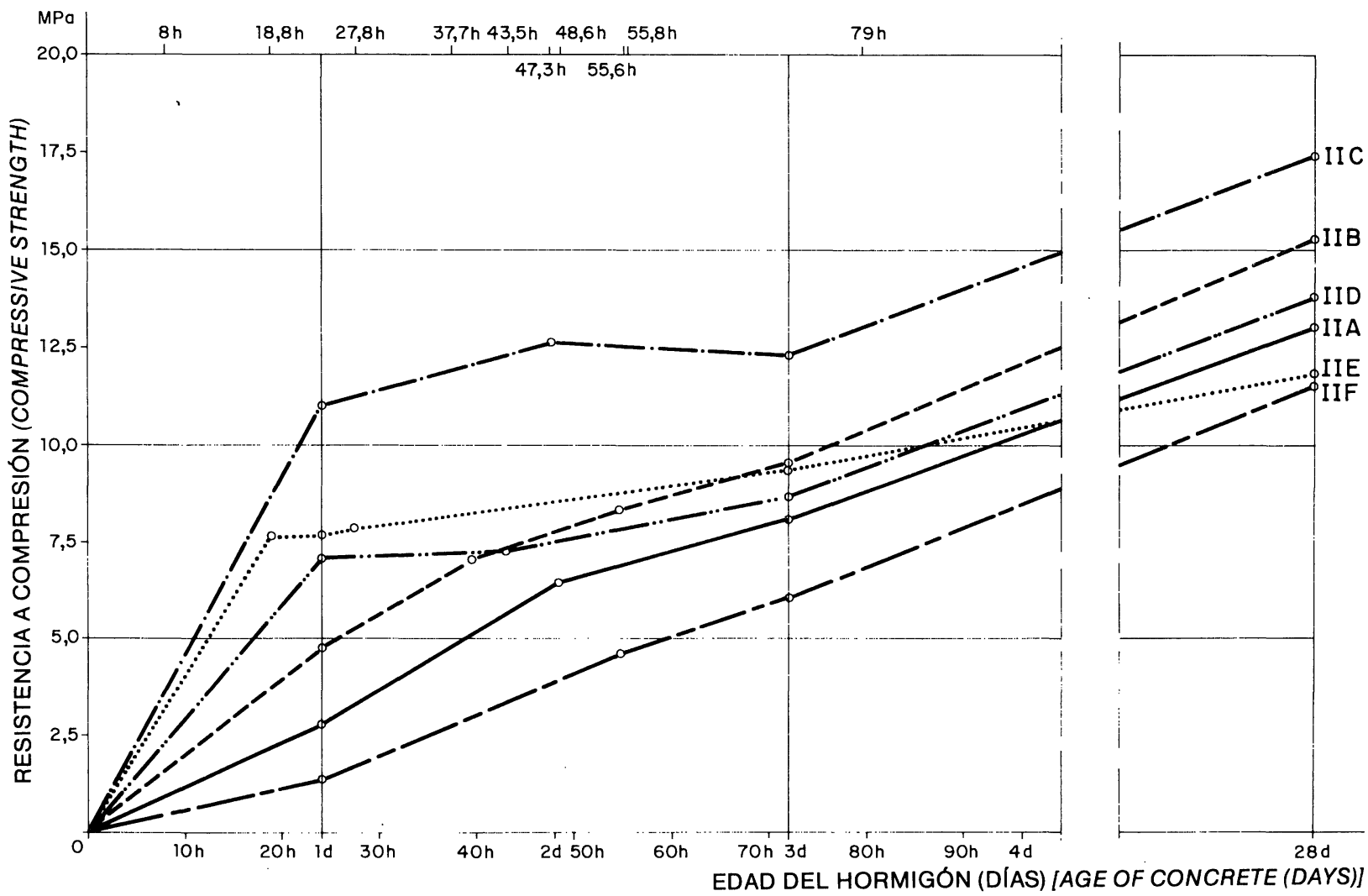

Fig. 3.-Desarrollo de resistencias de hormigón tipo ll en función de los curados.

Fig. 3.-Strength development of concrete "Type.II" by curing periods. 


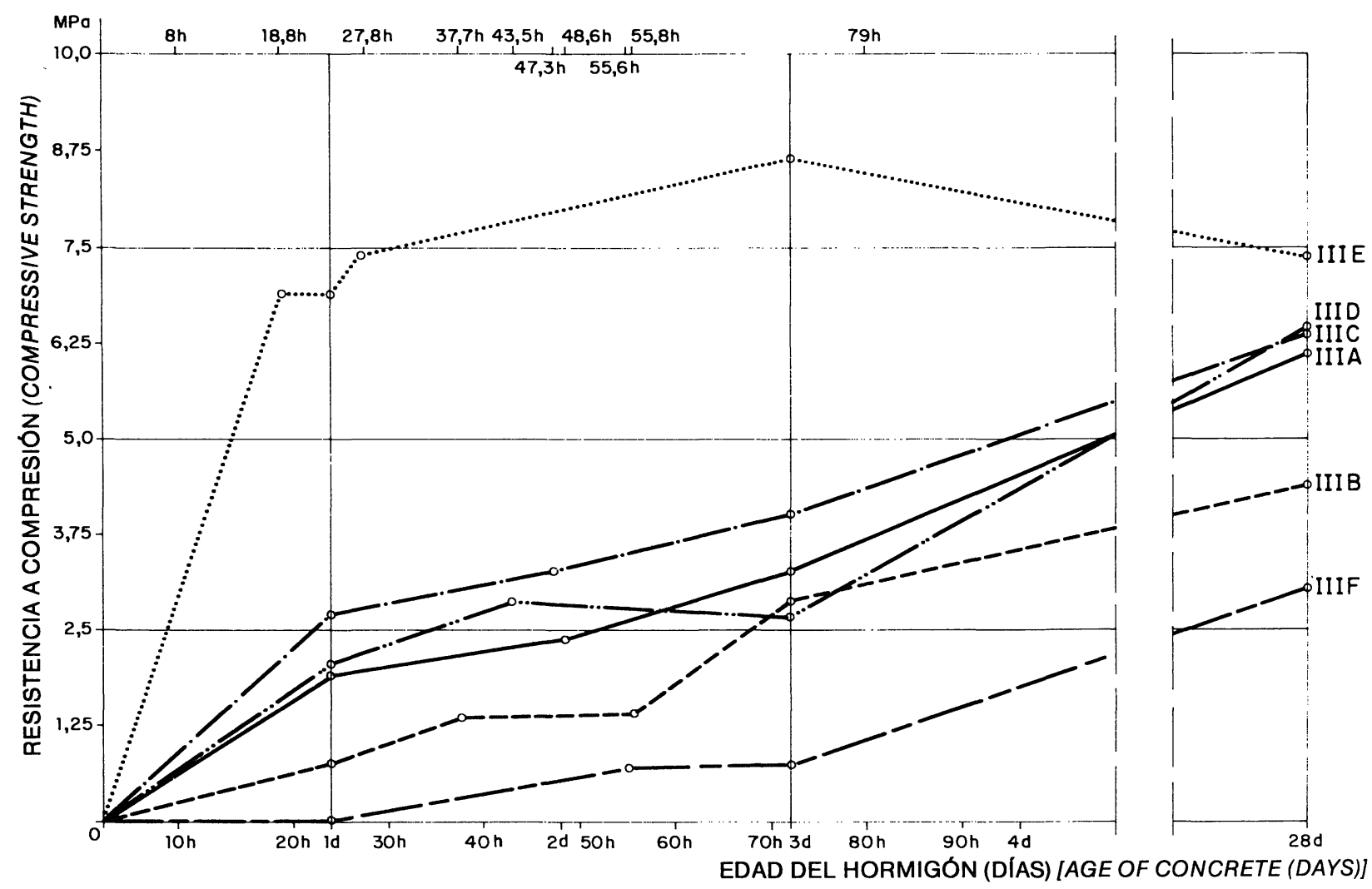

Fig. 4.-Desarrollo de resistencias del hormigón tipo III en función de los curados.

Fig. 4.-Strength development of concrete "Type III" by curing periods.

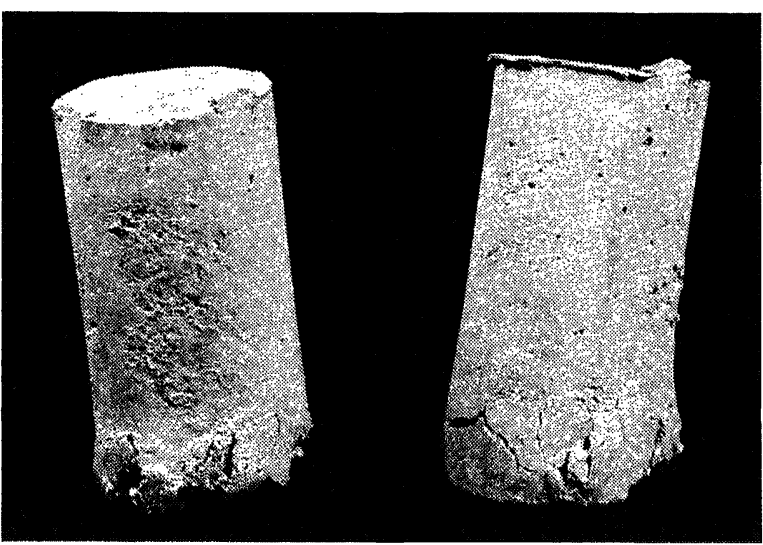

Foto 2.-Aspecto de las probetas de hormigón "Tipo III" tras ser sometidas al curado tipo " $F$ ", en el momento del desmoldeo.

Foto 2.-Apperance of type III concrete test pieces after submitting de type " $F$ " curing cycle in stripping moment.

MATERIALES DE CONSTRUCCIÓN, Vol. 40, n.0218, abril/mayo/junio 1990

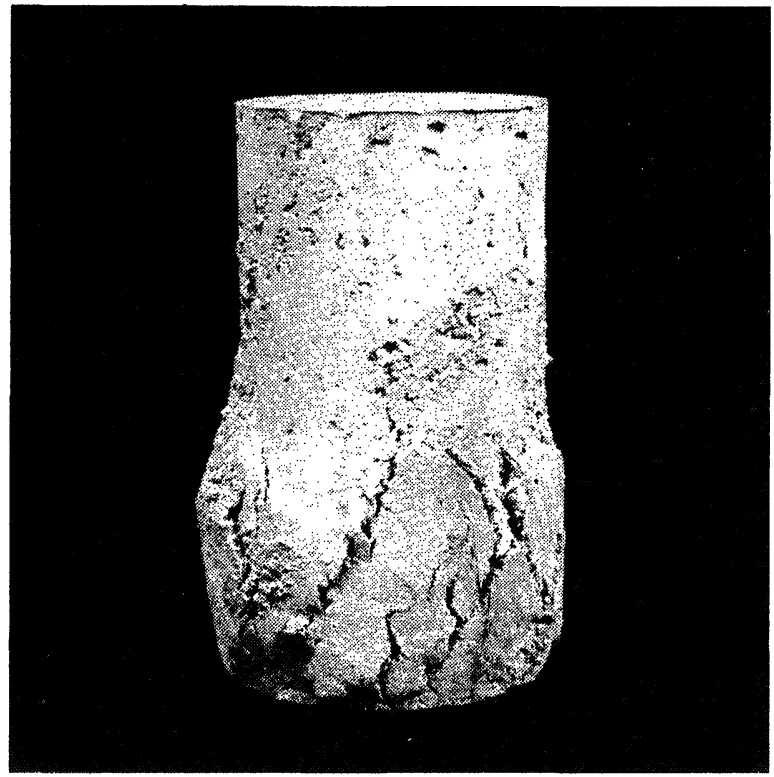

Foto 3.-Rotura a compresión de probetas de hormigón "Tipo III" tras ser sometidas al curado tipo "F".

Foto 3.-Compresive breaking of type III concrete test pieces after submmiting the type " $F$ " curing cycle.

43 
consecución de dos grados de madurez prefijados $(\alpha$ y $\beta$ ) y/o tres plazos fijos: uno, tres $y$ veintiocho días.

Resulta necesario el manifestar alguna de las incidencias ocurridas a causa del curado "tipo F". Debido al rigor de la baja temperatura $\left(-15^{\circ} \mathrm{C}\right)$ a la que se sometió el hormigón fresco, el momento del desmoldeo, ocho horas después del hormigonado, era tan evidente que incluso se manifestaba mediante ruidos en el interior de la masa del hormigón. En el desmoldeo se perdieron dos probetas tipo I y cinco del tipo III, por falta de resistencia ante el peso propio, con notable pérdida de la verticalidad (Foto 2 ).

La rotura de estas probetas en el momento del desmoldeo presentó, de forma generalizada, la forma de aplastamiento del tercio inferior de la probeta, tal y como muestra la Foto 3.

\subsection{Influencia de los diferentes tipos de curado sobre las resistencias a compresión}

Del análisis directo de los resultados recogidos en las Figuras 2, 3 y 4 se deducen las siguientes conclusiones especificas, para cada uno de los tipos de hormigones estudiados:

I.a. Se confirma la primacía del curado "tipo B", curado "Caribe", estudiado por los autores (6), respecto al resto de los curados estudiados, tanto a edades muy tempranas (casi $10 \mathrm{MPa}$ a las 24 horas), como a 28 días (20 MPa).

I.b. Los curados "tipo D y E" y en parte el "tipo C", es decir, los tres tipos de curado basados en un fuerte aporte energético inicial y que alcanzan temperaturas externas de $95^{\circ} \mathrm{C} ; 70^{\circ} \mathrm{C}$ y $65^{\circ} \mathrm{C}$ respectivamente, presentan resistencias algo superiores a las conseguidas mediante el curado normalizado ("tipo A") a cortas edades, aunque dañando claramente las resistencias diferidas, ya que a 28 días crecen muy tenuemente las resistencias a los casos " $D$ " y " $C$ ", llegando a decaer en el caso del curado "tipo E".

I.c. Sorprenden, aun siendo bajos, los resultados que llegaron a alcanzar las probetas sometidas al curado "tipo F" (con helada inicial) las cuales a 28 días alcanzaron $10 \mathrm{MPa}$.

Hormigones "tipo II", a base de cemento con adiciones: grades of maturity, $(\alpha, \beta)$ and/or three fixed periods: one, three and twenty-eight days.

It is necessary to point out some of the incidents took place as a result of "Type F" curing. Due to the low temperature $\left(-15^{\circ} \mathrm{C}\right)$ to which the fresh concrete was subjected, the moment of stripping, eight hours later, was so evident that it was even manifested by sounds coming from the interior of the concrete mass. Two Type 1 test pieces and five Type III pieces were lost upon stripping, due to lack of resistence to their own weight, and with considerable loss of verticality. (See Photo 2).

The breaking of these test pieces at the time of stripping resulted, in general, in the squashing of the lower third of the test piece, as shown in Photo 3.

\subsection{Influence of the Different Types of Curing on Compressive Strength}

From the direct analysis of the results shown in Figures 2, 3 and 4 one can deduce the following specific conclusions for each of the types of concrete studied:

I.a. The superiority of "Type B" curing, the "Caribbean" curing, studied by the authors (6) is confirmed with respect to the rest of the curings studied, both at early ages (almost $10 \mathrm{MPa}$ at 24 hours) and at 28 days (20 MPa).

I.b. The "Type D and E", and in part "Type C", that is to say, the last three curings based on a heavy initial energy use and which reach external temperatures of $95^{\circ} \mathrm{C}, 70^{\circ} \mathrm{C}$, and $65^{\circ} \mathrm{C}$, respectively, show somewhat higher strengths than those achieved through standard curing ("Type $A^{\prime \prime)}$ at early ages, although clearly at the expense of long-tern strengths, since at the end of 28 days the strengths of " $D$ " and "C" had increased only slightly, and in the case of "Type E" actually fell.

I.c. The results obtained by the test pieces subjected to "Type F" (initial treezing) curing are surprisig, despite still being low. At 28 days they reached $10 \mathrm{MPa}$.

"Type II" Concretes, based on cement with additions

MATERIALES DE CONSTRUCCIÓN, Vol. 40, n.0 218, abril/mayo/junio 1990 
II.a. Llama la atención, como conclusión global, el que los resultados a corta edad son sensiblemente parecidos a los conseguidos con hormigones "tipo I", pese a utilizar cemento portland de "alta resistencia inicial", y que a 28 días los resultados son menos dispersos, $y$, en general, mejores que los de "tipo I", superando con todos los tipos de curado los $10 \mathrm{MPa}$.

II.b. El curado "tipo C" — curado típico de procesos de prefabricación-, se muestra con claridad, especialmente a cortas edades, como el más adecuado para estos hormigones. Con resultados algo menores, pero con una evolución en el tiempo muy similar, se sitúa el curado "Caribe" o curado "tipo A".

II.c. Resulta reseñable y confirma la tónica de los resultados obtenidos con los hormigones "tipo I", la escasa ganancia de resistencia, transcurridos tres días de las probetas sometidas al curado "tipo E" (a temperatura de $70^{\circ} \mathrm{C}$ ).

Hormigones "tipo III", a base de un $60 \%$ de ceniza volante:

III.a. Son considerables las caídas de resistencias para todas las edades y curados, con relación a los hormigones "tipos I y II" estudiados. Prácticamente no se superan los $7,5 \mathrm{MPa}$, excepto para el curado "tipo E" que sigue detectando caídas de resistencia al pasar de 3 a 28 días.

III.b. Aun dentro de los pobres resultados obtenidos, se detecta que los procesos de curado con la aportación de calor ("tipos D, E y C") son los más apropiados para los hormigones con ceniza volante. Sorprenden los bajos resultados conseguidos mediante el curado "tipo B" a base de $30^{\circ} \mathrm{C}$ y $80 \%$ de H.R..

III.c. Los excelentes resultados relativos, conseguidos a edades muy tempranas $(18,8 \mathrm{~h} ; 24,0 \mathrm{~h}$ y $27,9 \mathrm{~h})$ con el curado "tipo E", alta temperatura $\left(70^{\circ} \mathrm{C}\right)$ y ambiente prácticamente saturado de humedad, confirma una vez más la efectividad de éstas con adiciones para los hormigones con alto contenido de cenizas volantes.

De las figuras 5 a 10 se deducen las siguientes conclusiones respecto de los efectos de los procesos de curado sobre las resistencias a compresión.
II.a. It is noteworthy that, as a general conclusion, the results obtained at early ages are very similar to those obtained with "Type I" concretes, despite having used Portland cement with "high initial strength". At 28 days, the results are less disparate and, in general, better than those of "Type I". More than $10 \mathrm{MPa}$ was obtained in all types of curings.

II.b. “Type C" curing, typical of prefabrication processes, is clearly, especially at early ages, the most adequate for these types of concretes. "Caribbean" curing and "Type A" curing showed somewhat lower results, but a similar evolution in time.

II.c. The scarce gain in strength after three days of the test pieces subjected to "Type E" curing (temperature of $70^{\circ}$ ) is worth noting, and confirms the tonic of the results obtained with "Type I" concretes.

"Type III" Concretes, based on $60 \%$ fly ash

III.a. The reductions in strength for all ages and curings are considerable relative to those of the "Type I" and "Type II" concretes studied. Practically none surpass 7.5 MPa, except for "type E" curing which continues to show drops in strength over the period from 3 to 28 days.

III.b. Despite the poor results obtained, it was detected that those curings using heat ("Types $D, E$, and C") are the most appropriate for concretes with fly ash. The poor results obtained through "Type $B$ " curing $\left(30^{\circ} \mathrm{C}\right.$ and $80 \%$ R.H.) are surprising.

III.c. The relatively excellent results obtain at very early ages (18.8 h., $24.0 \mathrm{~h}$, and 27.9 hr.) through "Type E" curing - high temperature $\left(70^{\circ} \mathrm{C}\right)$ and practically saturated surroundings - confirms once more the efficiency of these conditions for concretes with a high fly ash content.

The conclusions about the effects of curing processes on compressive strength can be drawn from Figures 5 and 10. 


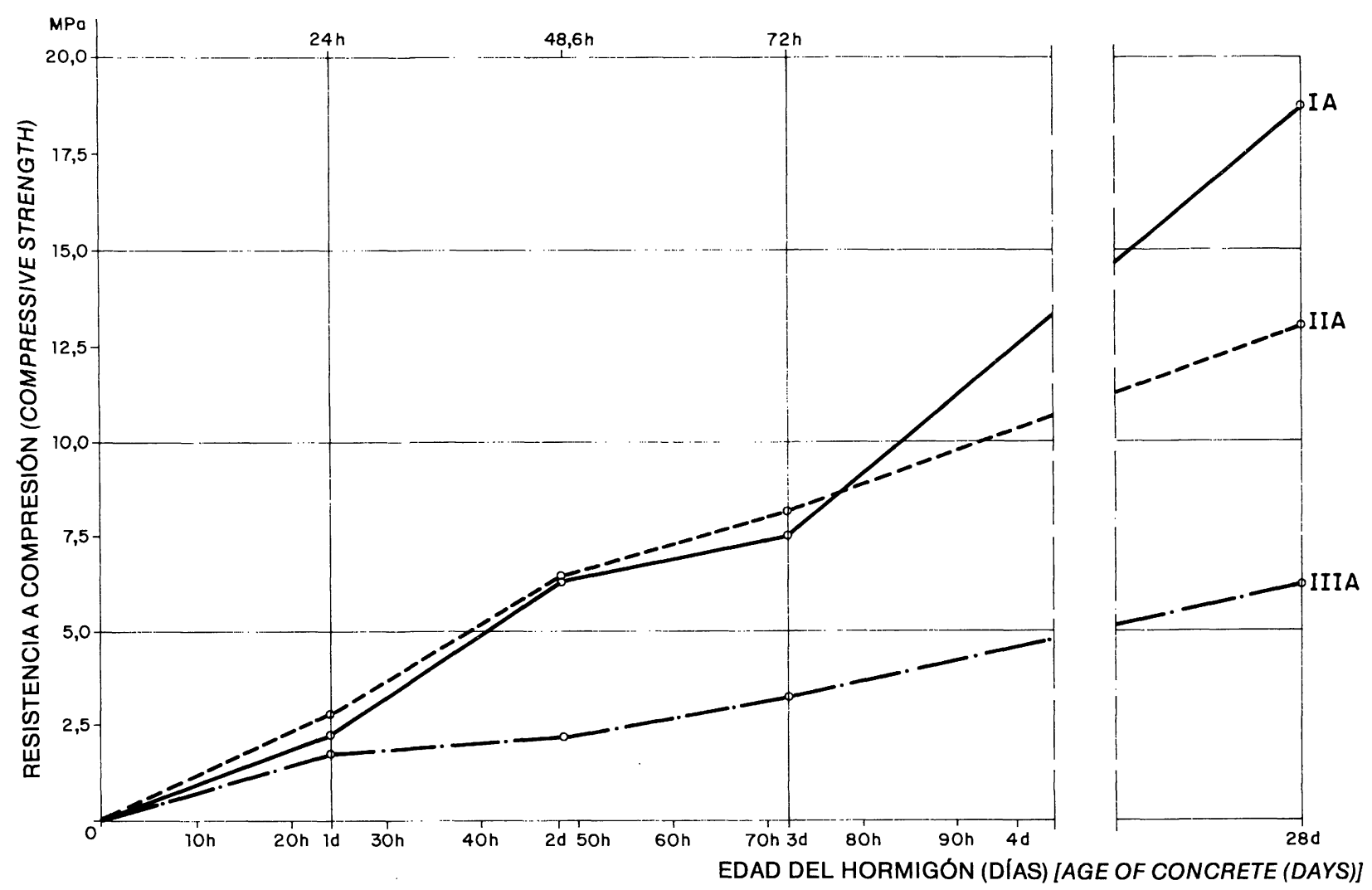

Fig. 5.-Desarrollo de resistencias de los distintos tipos de hormigón sometidos al curado "A".

Fig. 5.-Strength development of each concrete by "Type A" curing period.

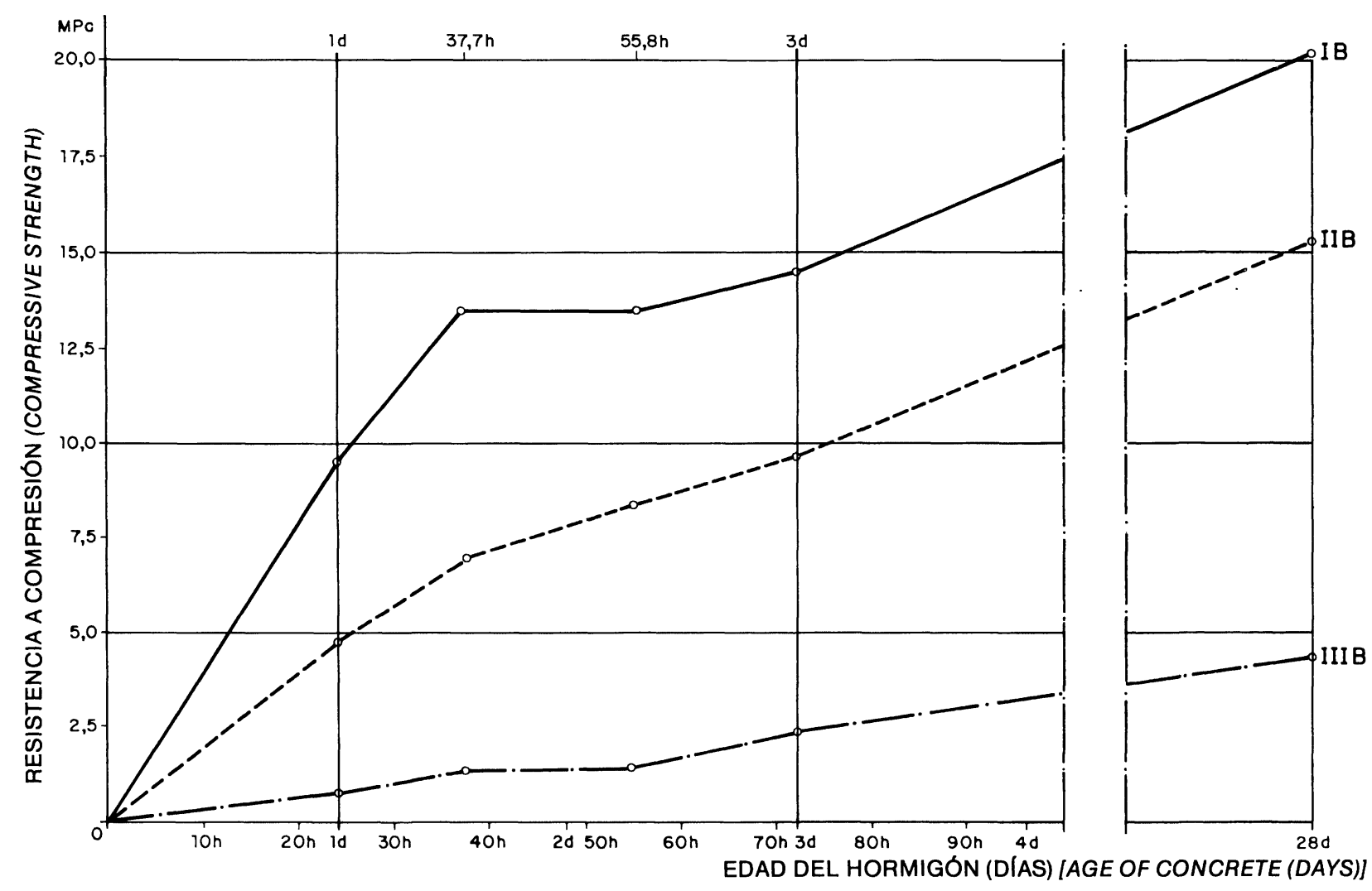

Fig. 6.-Desarrollo de resistencias de los distintos tipos de hormigón sometidos a curado "B".

Fig. 6.-Strength development of each concrete by "type B" curing period. 


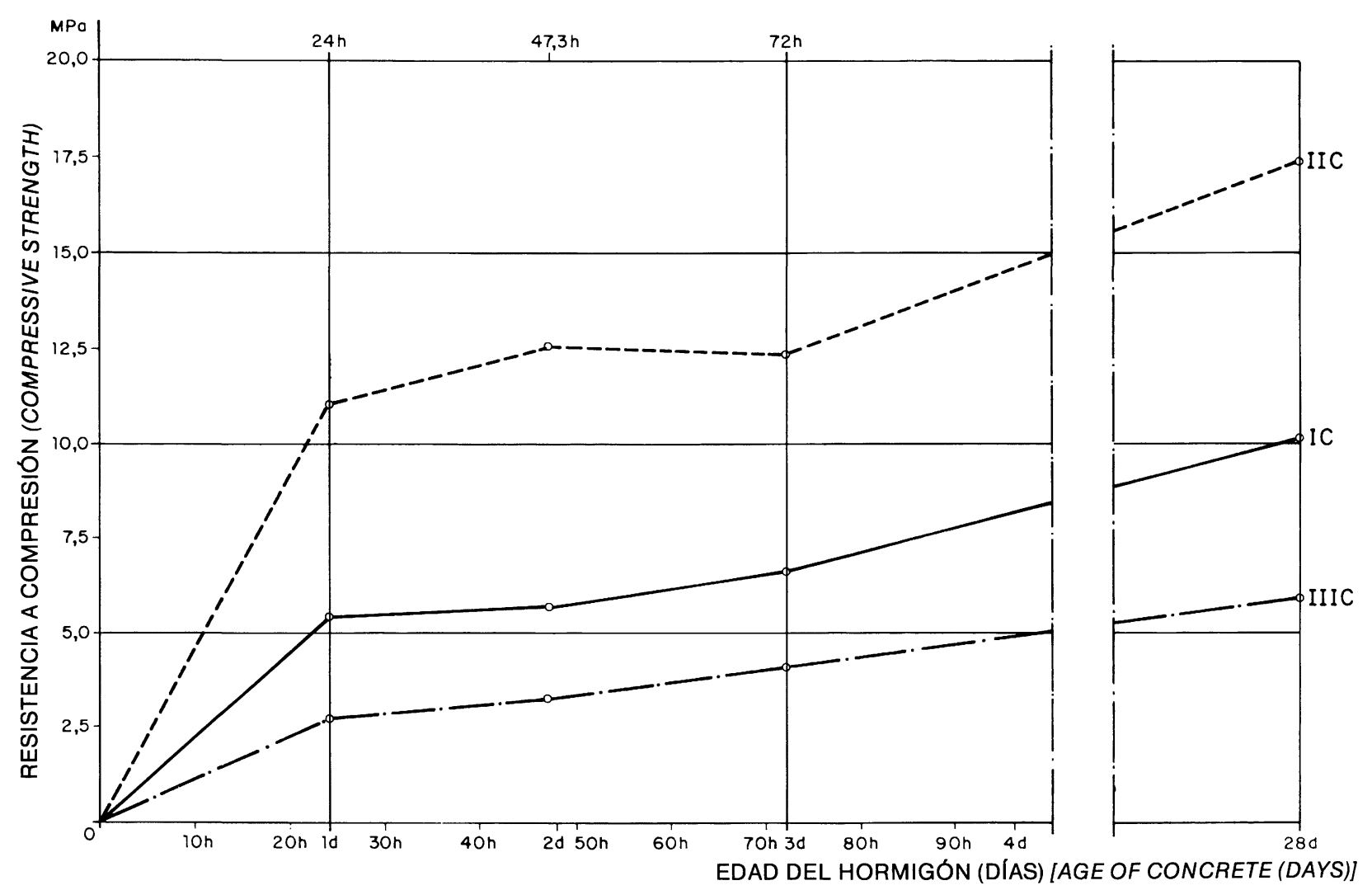

Fig. 7.-Desarrollo de resistencias de los distintos tipos de hormigón sometidos al curado "C".

Fig. 7.-Strength development of each concrete by "type C" curing period.

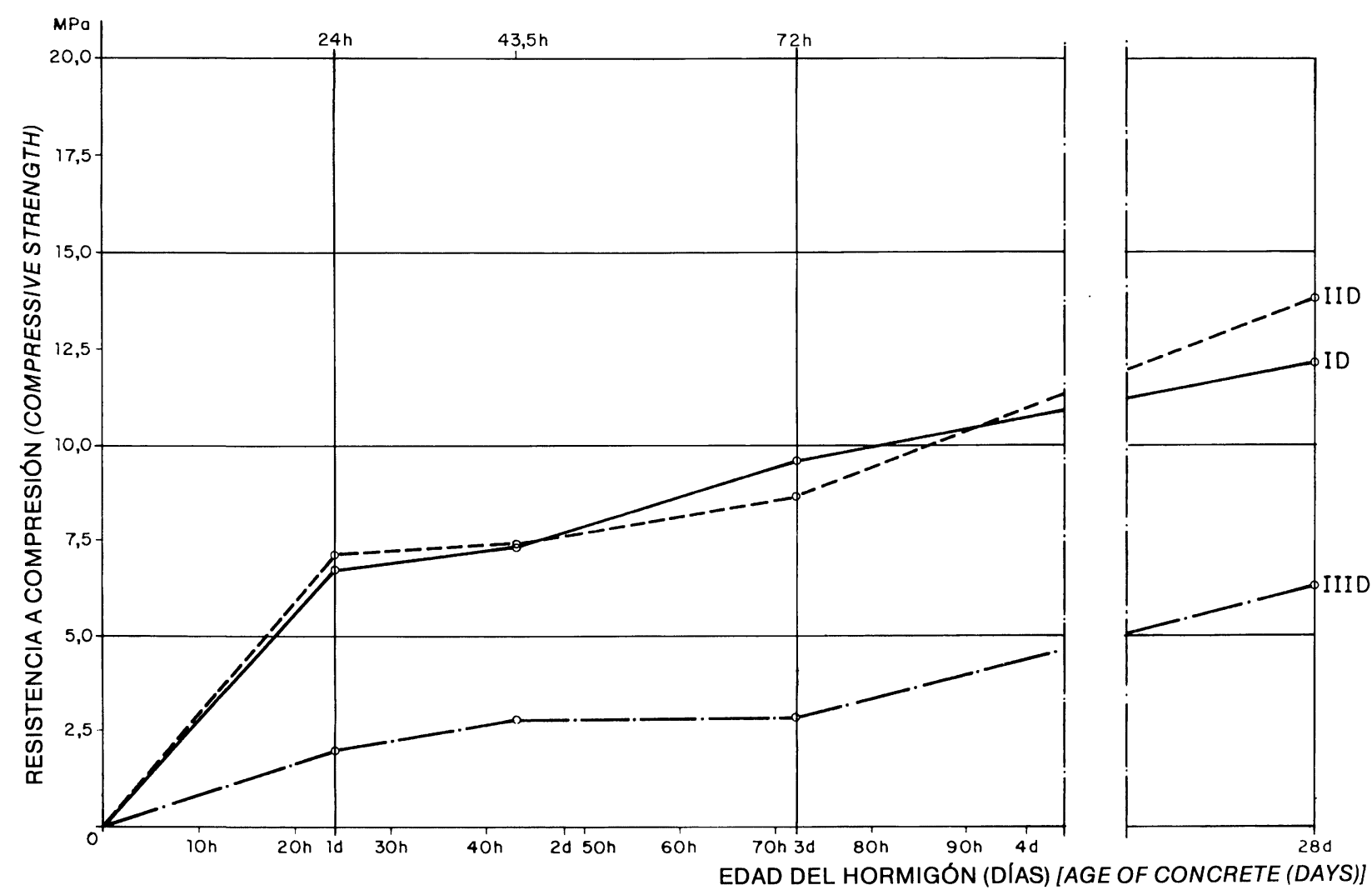

Fig. 8.-Desarrollo de resistencias de los distintos tipos de hormigón sometidos al curado " $D$ ".

Fig. 8.-Strength development of each concrete by "type D" curing period. 


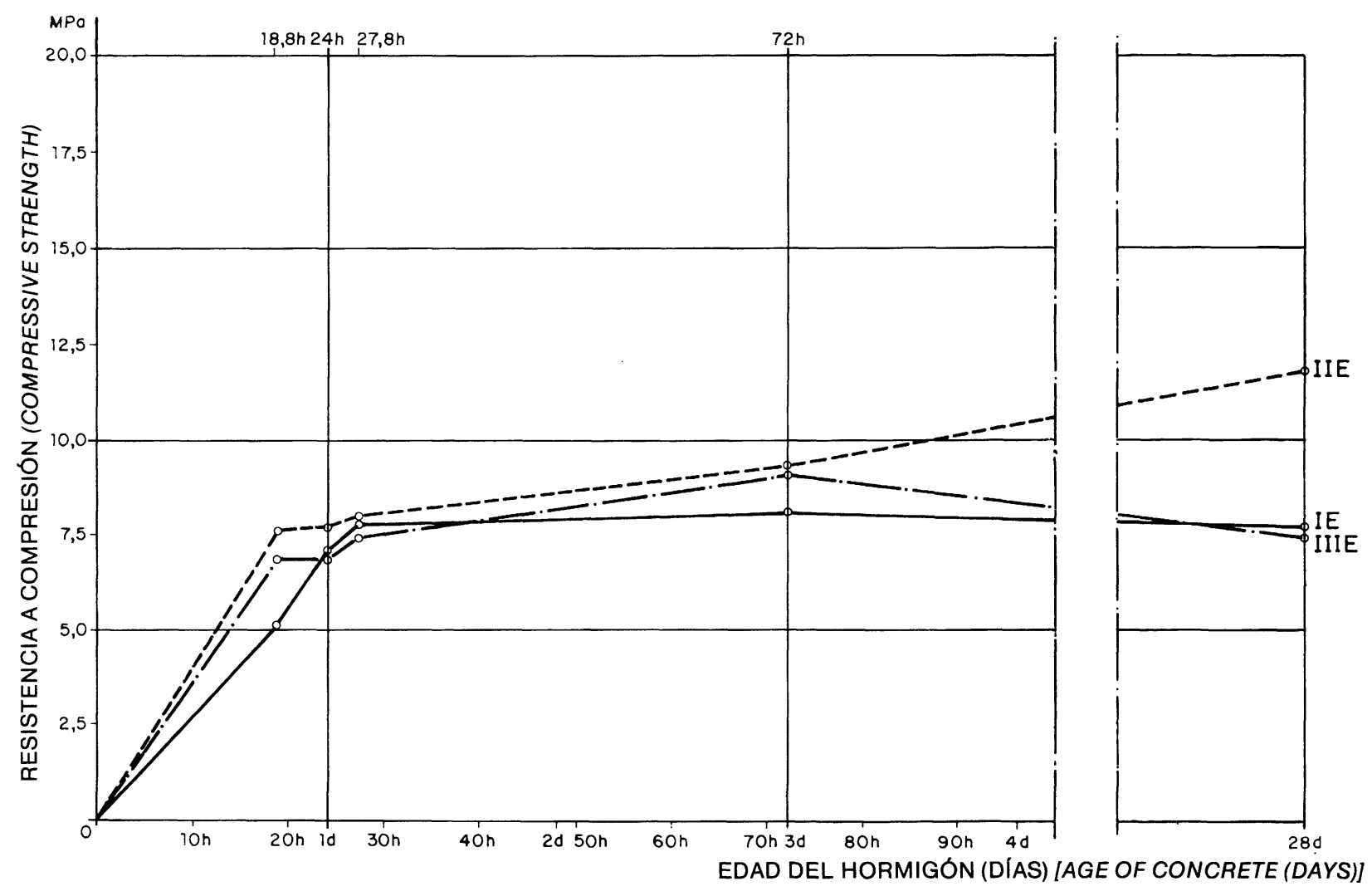

Fig. 9.-Desarrollo de resistencias de los distintos tipos de hormigón sometidos al curado "E".

Fig. 9.-Strength development of each concrete by "type E" curing period.

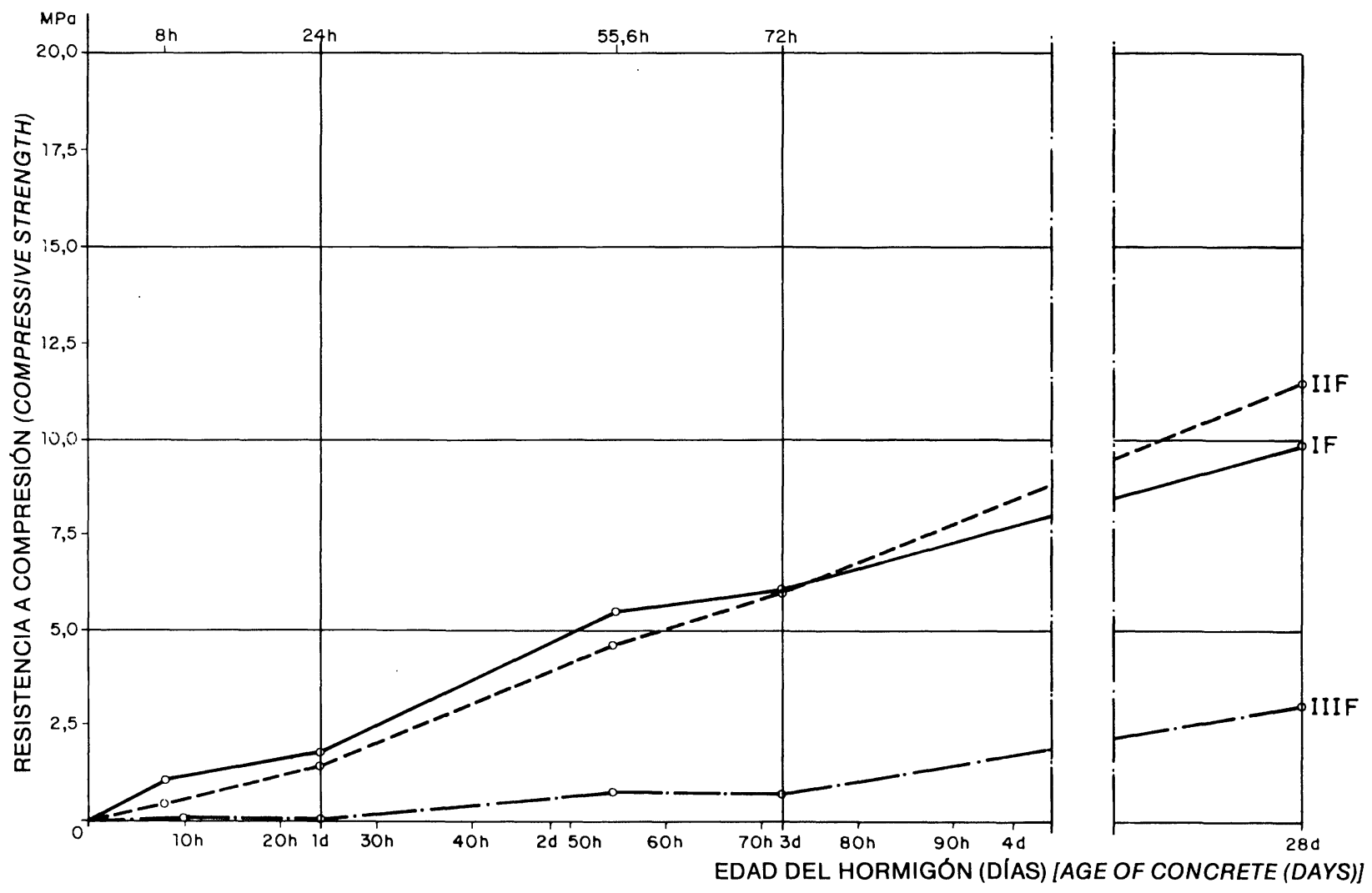

Fig. 10.-Desarrollo de resistencias de los distintos tipos de hormigón sometidos al curado "F".

Fig. 10.-Strength development of each concrete by "type F" curing period. 


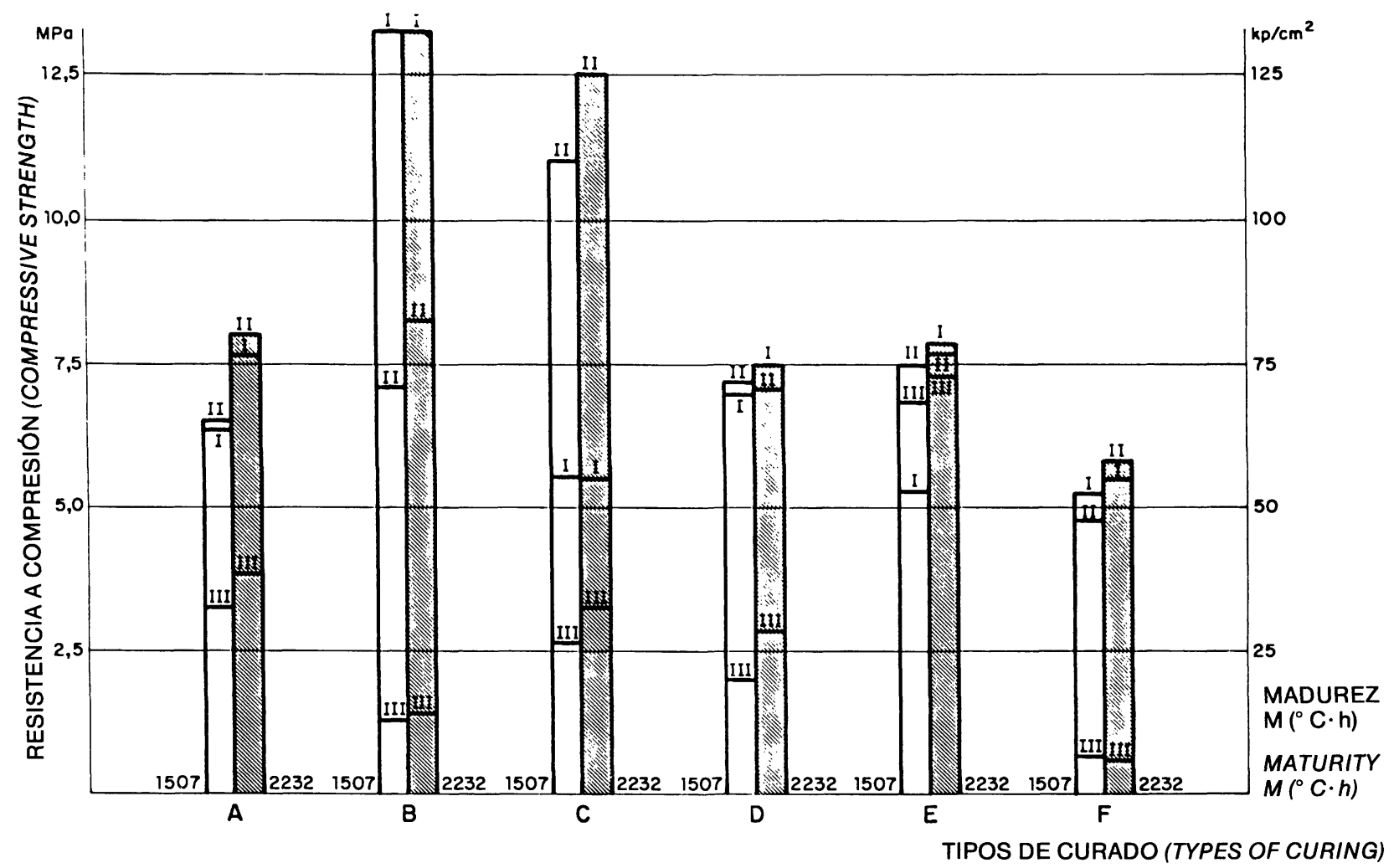

Fig. 11.-Relación entre madurez a edades tempranas ( $\alpha$ y $\beta$ ) y resistencia a compresión.

Fig. 11.-Relationship between early ( $\alpha$ and $\beta$ ) maturities and compressive strength.

\subsection{Influencia del grado de maduración sobre las resistencias a compresión}

La figura 11 aporta, en forma resumida, la notable influencia que existe entre los diferentes tipos de curado y dosficaciones sobre la resistencia a compresión del hormigón a cortas edades.

En lugar de tiempos de rotura se ha obtado por aportar resultados para los dos grados de maduración prefijados: $\alpha$ equivale a $1.507^{\circ} \mathrm{C} \cdot \mathrm{h}$, y $\beta$ a $2.232^{\circ} \mathrm{C} \cdot \mathrm{h}$.

Del mencionado gráfico se deducen las siguientes conclusiones:

A. A cortas edades, se presentan los siguientes curados como los más adecuados: el "tipo B" (Caribe) para el hormigón "tipo I" (cemento l/45A); el curado "tipo C" de (prefabricación) para el hormigón "tipo II" (cemento II-z/35), y el "tipo E" (saturado) para el hormigón "tipo III" (60\% ceniza volante).

B. Los hormigones "tipos I y II" a igual grado de maduración, 1.507 y $2.232^{\circ} \mathrm{C} \cdot \mathrm{h}$ presentan resistencias a compresión prácticamente idénticas, al ser sometidos a los curados "tipos A, D y F".

\subsection{Influence of Grade of Maturity on Compressive Strength}

Figure 11 shows, in summary form, the very notable influence of different types of curings and mixtures on the compressive strength of concretes at early ages.

Instead of breaking times, we opted to show results of the two pre-fixed grades of maturity: $\alpha$ equivilent to $1507^{\circ} \mathrm{C} \cdot h$ and $\beta$ at $2232^{\circ} \mathrm{C} \cdot h$.

The following conclusions can be drawn from said graph:

A. At early ages the following curings were found to be most adequate: "Type B" (Caribbean) for "Type I" concrete (I/45A cement); "Type C" curing (prefabrication type) for "type II" concrete (II-z/35 cement); and "Type E" curing (saturated) for "Type III" concrete (60\% fly ash).

B. "Type I" and "type II" concretes at the same grade of maturity, $1507^{\circ} \mathrm{C} \cdot \mathrm{h}$ and $2232^{\circ} \mathrm{C} \cdot h$, show practically identical compressive strengths when subjected to type $A, D$, and $F$ curings. 
C. El curado "tipo B" (Caribe) reporta ganancias de resistencia a compresión muy considerables para los hormigones a base de cemento tipo I/45A; tiene efectos no tan buenos como los hormigones "tipo II" y es desaconsejable para los del "tipo III".

D. El curado "tipo C" (prefabricación) reporta ganancias de resistencia a compresión muy considerables para los hormigones a base de cemento con adiciones; tiene efectos contraproducentes con los hormigones "tipo I" y se muestra neutro con los de "tipo III".
C. "Type B" curing (Caribbean) shows very considerable compressive strength gains for those concretes based on I/45. A cement, has not as positive an effect on "Type II" concretes, and is not advisable for "Type III" ones.

D. "Type C" curing (prefabrication) shows very considerable compressive strength gains for concretes based on cement with additions, has counterproductive effects on "Type I" concretes, and is neutral with regard to "Type III" ones.

\section{REFERENCIAS BIBLIOGRÁFICAS}

(1) NURSE, R. W.: "Physico-chemical fundamentals and methods of accelerated hardening of concrete". RILEM Symposium, Moscú, julio 1964.

(2) SAUL, A. G.: "Principles underlying the steam curing of concrete at atmospheric presure". Magazine of Concrete Research, 127-140; Marzo, 1951.

(3) KONO, K.; ARAKI, K. and SHINSHA, H.: "Relationship between Maturity and Compresive Strength of Steam-Cured Concrete". C.A.J. Review of the 28th. General Meeting, 1974. pp. 164-166.

(4) KOHNO, K.; HARADA, T. and KAWAKAMI, M.: "Investigations on Vibrating Compaction of Zero-Slump Concrete Using Iron-Blastfurnace Slag Fine Aggregate". J.C.I., Vol., 2, 1980, pp. 7-14.

(5) KOHNO, K. HORII, K. and FUKUSHIMA, H.: "Use of Fly ash, Blast-Furnace Slag and Condensed Silica Fume for Concrete Block Stripped Immediately After Molding". Congreso C.I.B., Stokolmo (Suecia), 1983, pp. 1165-177.

\section{publicación del ICCET/CSIC}
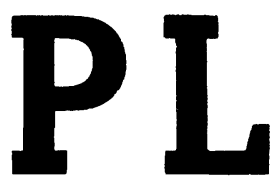
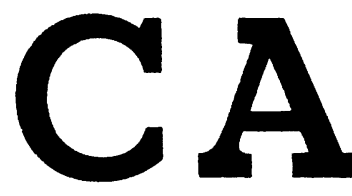

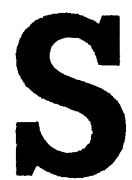

\section{K. Stiglat g H. Wippel}

Drs. Ingenieros

Traducción de Juan Batanero

Dr. Ingeniero de Caminos

con la colaboración de

Francisco Morán

Ingeniero de Caminos

Este libro, cuidadosa y magnificamente editado, reúne, quizás, la más completa colección conocida de tablas para placas, por los numerosos casos de vinculación y de carga estudiados y por la abundancia de relaciones de dimensión y de datos ofrecidos, que cubren prácticamente todo el campo de las losas en edificación. Permite desarrollar, con comodidad, rapidez y una aproximación suficiente, los cálculos de dimensionamiento y comprobación, obviando las dificultades que como es sabido, presenta el desarrollo numérico de los métodos de cálculo de estos elementos, evitando enojosas operaciones.

Trata la obra sobre "Zonas de Placas", "Placas sobre apoyos puntuales", "Placas apoyadas en dos, tres y cuatro bordes" y "Placas apoyadas elásticamente", tipos que en la actualidad disponian de una documentación, incompleta o nula, para la determinación de esfuerzos. Los corrimientos de la placa, como valores previos para la determinación de los momentos, han sido obtenidos por medio del Cálculo de Diferencias, método que se ha comprobado como suficientemente satisfactorio, aún en su forma simple, aplicado con un cierto control.

Un volumen encuadernado en tela, de $30,5 \times 23,5 \mathrm{~cm}$, compuesto de 92 págs. Madrid, 1968.

Precios: España, 2.500 ptas.; extranjero, $\$ 36.00$. 